\title{
Figurações do "mal" e do "maligno" \\ no Grande sertão: veredas
}

\author{
MARCUS V. MAZZARI
}

\begin{abstract}
"Mas ele é eu, Aliócha, eu mesmo. Tudo o que há de baixo em mim, tudo o que há de torpe e desprezível em mim! [...] Ele é tremendamente estúpido, mas por isso vence. É ladino, animalescamente ladino, sabe como me deixar furioso. Só fez me provocar, dizendo que eu creio nele, e com isso me obrigou a ouvi-lo."
\end{abstract}

(Dostoiévski, Os irmãos Karamázov, 2008)

S E A FACE demoníaca - "cara de gente, cara de cão" - que bruxuleia no início do Grande sertão é atribuída de imediato à crendice de um "povo prascóvio", mesmo assim o leitor pode sentir-se remetido a uma esfera que talvez não seja coisa de nonada. Pois ainda que Riobaldo não duvide se tratar apenas de uma aberração da natureza - muito distante, portanto, de algo como o olhar mortífero do Basilisco ou a face gorgônica da Medusa -, a superstição popular parece tê-la concebido naquele âmbito que Mefistófeles, desprendendo-se do disfarce de cão e surgindo pela primeira vez diante de Fausto, diz constituir o seu elemento mais genuíno, isto é, o Mal: "Por isso, tudo a que chamais / De destruição, pecado, o mal,/ Meu elemento é, integral”. ${ }^{1}$

Numa dicção estranha, mas que logo se nos tornará familiar e inconfundível, as considerações iniciais em torno do "bezerro erroso" começam não apenas a se insinuar nos domínios em que se entrecruzam concepções do mal e do maligno, mas também a delinear uma posição narrativa que sentimos como eminentemente moderna. Desse modo, antes de qualquer possível travo de extemporaneidade ou obsoletismo na história romanesca ainda por abrir-se, os "causos" que vão se atraindo e revezando uns aos outros nas páginas iniciais do livro começam a despertar no leitor a impressão de estar diante de uma obra efetivamente contemporânea do grande romance de Robert Musil ou da ficção autobiográfica de Marcel Proust. Uma frase bem construída no início de uma narrativa tende, em exposição concisa e já marcando o tom predominante, a incrustar-se de maneira indelével na memória do leitor, como ilustram, entre outros possíveis exemplos, O homem sem qualidades, Du côté de chez Swann, também a novela $A$ metamorfose, ou ainda - em plano mais modesto - o nosso 
Ateneu, com o alexandrino que o narrador, cindindo-o com breve comentário, coloca nos lábios do pai: "VVais encontrar o mundo', disse-me meu pai, à porta do Ateneu. "Coragem para a luta". Do mesmo modo, a abertura do Grande sertão, com o seu "Nonada" alteando-se após o travessão e as palavras que, deflagradas pelos tiros recém-soados, confrontam o leitor, de imediato, com uma perspectiva narrativa e uma tonalidade que atravessarão, ao longo de centenas de páginas, não só as inúmeras outras historietas, digressões, especulações, vivências - veredas narrativas que brotam e se ramificam profusamente do fluxo "sem ordem" do antigo jagunço -, mas também o caudal romanesco margeado pelas vicissitudes da relação com Diadorim e da guerra que se desdobra no espaço épico do grande sertão.

As considerações iniciais sobre manifestações do demo nesses domínios indeterminados, em que "os pastos carecem de fecho", logo se entrelaçam, com o leitor mal percebendo a passagem, com “causos" em torno da maldade humana. O discurso transita assim, como já sugerido, do mal para o maligno (do evil para o devil, do gênero neutro das Böse para o masculino der Böse, para explorar aqui possibilidades das línguas inglesa e alemã); transportados desse modo àquele elemento que Mefisto dissera ser genuinamente o seu, "integral", vemo-nos ao mesmo tempo diante de uma questão central do pensamento moderno, concernente ao sentido, ao porquê do mal no mundo. ${ }^{2}$

Não seria de supor que Riobaldo - e com ele o próprio autor do Grande sertão - compartilhasse da concepção filosófica, constituída na chamada "esquerda hegeliana", segundo a qual a idéia de Deus não significa outra coisa senão a projeção antropomorfizada da essência da espécie humana: "Homo homini Deus est", como diz a célebre fórmula de Ludwig Feuerbach, a cujo pensamento o suíço Gottfried Keller levanta um monumento no último livro de seu romance $O$ verde Henrique. No entanto, Riobaldo talvez não tivesse muito a objetar quanto ao reverso possível daquela concepção, isto é, que também o diabo não representaria outra coisa senão a catalisação personificada da maldade humana ou, indo mais além, dos males que se observam no mundo e se atribuem às esferas física, metafísica e moral. "Satanas sum et nibil humani a me alienum puto", já dissera, aliás, o diabo de Dostoiévski a Ivan Karamázov, sugerindo a substância humana que o constitui.

Ver no nascimento de um bezerro deformado mais uma manifestação do diabo, isso só é possível no âmbito de um espaço de "subdemonidade", para valer-se aqui do neologismo com que Thomas Mann, em seu Doutor Fausto, faz o narrador caracterizar a fictícia cidade-natal de Adrian Leverkühn, a Kaisersaschern na região da Turíngia, não distante do castelo (Wartburg) em que Lutero atirou certa vez um tinteiro contra o "Tentador", deixando na parede uma mancha que até hoje constitui atração turística. Nas terras de subdemonidade pintadas pelo ex-jagunço Riobaldo na abertura do relato encontramo-nos evidentemente muito distantes do mundo da alta cultura que Serenus Zeitblom 
nos descortina em sua narração, mundo em que se formou o pensamento de Friedrich Nietzsche e onde professores do jovem Leverkühn destrinçam os nexos íntimos entre teologia e demonologia (em especial, no capítulo XIII). Em ambos os romances vigora, no entanto, a mesma verossimilhança que enlaça, com toda maestria artística, o espaço físico, um substrato espiritual rústico de um lado e erudito de outro, o foco narrativo de um sertanejo e, no contexto alemão, de um professor humanista. Assim, a crença de que um animal monstruoso tenha vindo ao mundo sob influxo demoníaco só é plenamente verossímil no relato de Riobaldo: "O senhor tolere, isto é o sertão". Logo vem então a referência a dois moradores da região: o Aristides da "Vereda-Mansa-de-SantaRita", que passando por três certos lugares faz soar sempre a vozinha chorosa do “capiroto", e o Jisé Simpilício com o seu spiritus familiaris sertanejo, o "miúdo satanazim" que mantém guardado em casa para o seu benefício econômico. Toleramos de muito bom grado essas duas historietas, assim como o recente boato, narrado na seqüência, de que o próprio diabo, sob a aparência de um "Moço de fora", apareceu no povoado de Andrequicé após um percurso de apenas "uns vinte minutos", em vez do dia-e-meio que leva a cavalgada costumeira. Parece sem dúvida um portento, do qual talvez nos lembremos centenas de páginas adiante, ao depararmos com a travessia do Liso do Sussuarão - não menor portento - empreendida agora sob o comando do Riobaldo já na suposta condição de pactário.

O grassar do diabo nos Evangelhos, que o narrador lembra em seguida, enseja a primeira referência à figura de Quelemém de Góis, cujo significado para a vida posterior de Riobaldo (isto é, após a aventura romanesca) ajudará a deslocar a história narrada da trilha fáustico-demoníaca para a dimensão do aperfeiçoamento e da aprendizagem. Na visão do kardecista Quelemém, o que há mesmo são "baixos espíritos de terceira, fuzuando nas piores trevas e com ânsias de se travarem com os viventes" - encosto que terão dado nos nove nomes que, de Rincha-Mãe a Hermógenes, surgem soltos ao leitor e, ainda nas páginas iniciais, parecem soar-lhe como nova antecipação pressagiosa.

Já está dada a ocasião para Riobaldo formular uma questão obsedante em sua existência ("O diabo existe e não existe?"), que se faz acompanhar do primeiro acorde no leitmotiv do "viver perigoso". Mas o narrador que, mesmo se situando num espaço arcaico impregnado de crendices e "abusões", vai delineando um ponto de vista admiravelmente moderno, já antecipa também uma experiência fundamental de sua existência, isto é, que no fundo "o diabo vige dentro do homem, os crespos do homem - ou é o homem arruinado, ou o homem dos avessos". Introjeta-se assim o que num primeiro momento terá nascido do movimento inverso, ou seja, a exteriorização antropomorfizante de ações e tendências humanas. Por um lado, portanto, o diabo não existe, pois do contrário - nova antecipação inquietante - ninguém mais do que o próprio narrador estaria apto a confrontá-lo. Por outro, porém, a dialética sertaneja de 
Riobaldo postula na seqüência que o diabo se manifesta não apenas nos homens, mulheres e crianças, mas também nos bichos (no "ódio franzido" de uma cascavel, na voracidade e "suja comodidade" de um porco, na "precisão de talhar para adiante, rasgar e estraçalhar a bico" de uma ave-de-rapina), assim como no reino vegetal (a mandioca-brava peçonhenta) e mineral ("tortas raças de pedras, horrorosas, venenosas - que estragam mortal a água”).

Desse modo, o sinuoso curso das especulações riobaldianas, sempre balizado por afirmativas e negaças ( "É, e não é. O senhor ache e não ache. Tudo é e não é...”), acaba criando uma transição da esfera do maligno para a do mal. Pois aos "causos" do Aristides e do Jisé Simpilício, o narrador faz corresponder simetricamente dois outros igualmente contemporâneos do tempo da enunciação: o do Aleixo com suas quatro crianças que ficam cegas após a maldade gratuita cometida pelo pai, e, logo após, a de Pedro Pindó com seu filho Valtêi, menino que, na precocidade de seus atos e palavras ("Eu gosto de matar"), surge a Riobaldo como "passarinho que se debruça - o vôo já está pronto!". Contudo, mais do que exemplificar o mal que ainda viceja em torno do velho narrador, as historietas mostram a sua relação de reversibilidade com o bem: a transformação do Aleixo num homem caridoso e temente a Deus e, como movimento contrário, a crescente atração com que o mal, sob a forma de sadismo, vai atraindo Pindó à sua esfera, sob o pretexto de corrigir as inclinações perversas do filho. O sofrimento das crianças levanta perplexidade e indignação no narrador: o Valtêi com sua "carinha de ossos, encaveirada", já no "blimbilim", e "uma escadinha - três meninos e uma menina - todos cegados". Virão então as explicações kardecistas de Quelemém, mas mesmo essas não soam plenamente convincentes: "Se sendo castigo, que culpa das hajas do Aleixo aqueles meninozinhos tinham?!". O neologismo "hajas" talvez não esteja sendo empregado aqui de maneira fortuita, pois poderá ganhar surpreendente elucidação se confrontado, quase cinqüenta páginas adiante, com uma convicção fundamental de Riobaldo, cuja formulação se assenta na contraposição entre o "existir" de Deus e o "haver" do diabo: "Deus existe mesmo quando não há, mas o diabo não precisa existir para haver".

Se é, portanto, por meio das "hajas" do Aleixo que o diabo impõe presença no mundo, o reverso dessa formulação não se sustenta no mundo das especulações riobaldianas, ou seja, não seria a existência do maligno que leva os seres humanos a perpetrarem maldades. Conhecemos as várias e sempre expressivas formulações do Grande sertão em que se opõem, à semelhança da antes mencionada (o "existir" de um, o "haver" do outro), as concepções que o eunarrador faz do divino e do demoníaco. Seja pela sua beleza literária, seja pela eventual sabedoria que encerra - o "lado épico da verdade"3 que toca a crentes, agnósticos ou ateus - torna-se difícil resistir ao impulso de reproduzi-las e comentá-las. Talvez seja lícito sustentar que todas essas formulações antológicas de Riobaldo ilustram ao seu modo as palavras que Deus, no magnífico "Prólogo 
no céu" do Fausto goethiano, dirige a Mefistófeles ao conceder-lhe permissão de arrastar o seu servo pelas estradas do mal: "Que o homem de bem, na aspiração que, obscura, o anima,/ Da trilha certa se acha sempre a par" (v.328-29). Para uma tal concepção, tanto o mal como o maligno devem revelar-se por fim como "instrumento" da ordem divina, conforme já expõe de maneira paradigmática a história bíblica de Jó, importante fonte do "Prólogo no céu".

Traduzida para a dimensão sertaneja, essa teodicéia se manifesta em mais um caso que Riobaldo desdobra ao leitor ainda no preâmbulo do relato romanesco, nas páginas iniciais do livro. Trata-se de seu encontro, durante uma viagem de trem a Sete-Lagoas, com o delegado Jazevedão, cuja descrição fisionômica realça os traços de extrema brutalidade. Como nas historietas do Aleixo e do Pedro Pindó, levanta-se também nesse episódio do trem-de-ferro a questão relativa ao sentido do mal no mundo: "um assim, devia de ter, precisava?". A resposta, todavia, não mais se configura quanto à sua reversibilidade com o bem, mas justamente no âmbito de uma ordem em que tal Jazevedão (com o reluzir "crú nos olhos pequenos", "queixo de pedra", "presa pontuda de guará"), atua inconscientemente como "feio instrumento" que, ao fim e ao cabo, e mesmo por trás da aparência de inescrutabilidade, obedeceria aos desígnios divinos. Pois o ruim com o ruim, eis outra elaboração filosófica da longa experiência de vida do eu-narrador, "terminam por as espinheiras se quebrar - Deus espera essa gastança".

Se, por um lado, foge às possibilidades do velho Riobaldo conhecer de que modo o jovem delegado irá ainda quebrar a própria "espinheira" e pagar as "hajas" praticadas como representante da lei, por outro, o sentido positivo de sua existência no mundo do sertão elucida-se no contexto de um processo modernizador incompatível com o fenômeno social do jaguncismo, combatido e suprimido a ferro e fogo por homens como Jazevedão: "Senhor pensa que Antonio Dó ou Olivino Oliviano iam ficar bonzinhos por pura soletração de si, ou por rogo dos infelizes, ou por sempre ouvir sermão de padre?".

Além de conceber o monopólio do poder e da violência por parte do Estado como um bem (um dos momentos questionáveis do grande livro), a observação de Riobaldo constitui um primeiro ensejo para apresentar ao leitor um fragmento da história romanesca, pois aos nossos olhos se desenrola então o episódio da epifania de Joé Cazuzo, o único "jagunço comportado ativo para se arrepender no meio de suas jagunçagens". De "entrante do demônio" - como já se definira a condição jagunça - a "homem mais pacificioso do mundo", a conversão de Cazuzo, atingido por espécie de relâmpago de Damasco em meio a um tiroteio com soldados do coronel Adalvino, é pinçada de uma etapa bastante avançada da guerra jagunça - uma peça que o leitor terá de encaixar, no puzzle do enredo, pouco antes da morte de Medeiro Vaz.

Esse primeiro afloramento da história romanesca na narração, motivado concretamente pela figura do Jazevedão, não se sustenta, porém, por muito 
tempo. Logo o narrador volta aos seus "causos", retorna a especulações e divagações que, não fosse a instância de controle exercida pelo ouvinte da cidade, poderia muito bem valer-se do monologue intérieur ou mesmo do stream of consciousness, liberando - nas palavras de Auerbach - "idéias e cadeias de idéias que abandonam o seu presente para se movimentarem livremente nas profundidades temporais". Do elogio do então moderno trem-de-ferro, propiciador de pensamentos e insights, o narrador salta para uma indagação teológica que até parece ecoar concepções de Orígenes sobre a demorada purificação da alma em seu percurso para o céu, passando por inúmeras mansiones celestes. $\mathrm{O}$ tema da remissão dos pecados puxa a lembrança do Firmiano, vulgo Piolho-de-Cobra e descendente de índios, cuja saudade da antiga jagunçagem, acompanhada do desejo de castrar, esfolar e matar um soldado, enseja a estranha generalização de Riobaldo: "Quem tem mais dose de demo em si é índio, qualquer raça de bugre". Novas especulações sobre a ida ao céu, sobre a constante metamorfose das pessoas, que "afinam ou desafinam"; depois outra preciosa lição de vida: "o diabo, é às brutas; mas Deus é traiçoeiro", seguida da parábola da faquinha com cabo de madeira mergulhada num tanque.

Está dado o ensejo para nova apologia da religião e da prece, a qual leva de imediato à situação atual do fazendeiro Riobaldo, cercado por meeiros dos antigos tempos de jagunçagem, mas todos agora respeitosos da ordem - e daí a advertência ao ouvinte e leitor: "Também, não vá pensar em dobro". Uma breve referência à mulher Otacília, outra mais breve ainda a Diadorim - "mas Diadorim é a minha neblina..." -, e aflora à boca desordenada do narrador a já citada antecipação ominosa do pacto: “Agora, bem: não queria tocar nisso mais - de o Tinhoso; chega. Mas tem um porém: pergunto: o senhor acredita, acha fio de verdade nessa parlanda, de com o demônio se poder tratar pacto?”. A narração parece reagir então a considerações do interlocutor, mesmo ao propósito de partir antes da manhã de quinta-feira, isto é, dos três dias que deve durar uma visita, consoante regra do sertão. Pelo visto, o hóspede e ouvinte pretende percorrer essa região de pastos ilimitados e, assim, Riobaldo se atribui o papel de guia turístico, descrevendo com largueza épica e sensibilidade lírica parte das "belezas sem dono" que conheceu sob orientação e inspiração de Diadorim. O trecho culmina numa enumeração ornitológica, arrematada por pássaros (papa-banana, azulejo, garricha-do-brejo, suiriri, sabiá-ponga, grunhatá-do-coqueiro...) que cantam o crepúsculo - momento em que a saudade, lembrando-nos da abertura do canto VIII do Purgatório, volta ao coração com força mais enternecedora e o amor punge então o "peregrino" que ao longe ouve sons anunciando o ocaso do dia. Do mesmo modo como no episódio do Joé Cazuzo - primeira entrada no tema da guerra - o nome Diadorim surgira acompanhado pelo canto de um joão-congo, agora são esses pássaros do entardecer que preludiam nova entrada na história romanesca pela mão do amigo - "Eu estava todo o tempo quase com Diadorim. Diadorim e eu, nós dois. A gente dava passeios". Ao mesmo tempo, 
assinala-se o término de um prólogo dominado largamente pela preocupação com o mal e as formas de manifestação do maligno no mundo do sertão.

Neste momento, passamos a navegar uma torrente narrativa mais caudalosa, partindo porém de um ponto avançado da história, o que dificulta sobremaneira a orientação no âmbito de uma primeira leitura. Essa segunda entrada no tema da grande guerra jagunça se estenderá por aproximadamente 72 páginas, até desembocar numa referência antecipatória e, mais uma vez, pressaga ao espaço físico das Veredas Mortas ("Eu disse, o senhor não ouviu") e do arraial do Paredão ("O senhor não me pergunte nada"). O fio narrativo que se iniciara em flagrante oposição ao ordenamento cronológico é então suspenso por novas considerações de Riobaldo sobre sua incapacidade de organizar a história - de oferecer ao leitor uma "seqüência ordenada dos fatos" e reproduzir "a estonteante multiplicidade da vida num plano unidimensional", para valer-se de formulações que Robert Musil desdobra no Homem sem qualidades. ${ }^{4} \mathrm{~A}$ declaração de Riobaldo soa como uma desculpa perante o leitor: "Sei que estou contando errado, pelos altos. Desemendo. Mas não é por disfarçar, não pense. [...] Contar seguido, alinhavado, só mesmo sendo as coisas de rasa importância. [...] E estou contando não é uma vida de sertanejo, seja se for jagunço, mas a matéria vertente". No entanto, é justamente após essa declaração de princípio, norteada pela primazia da "matéria vertente", que o narrador decide recuar no tempo e recuperar finalmente a ordem cronológica que se inicia com o episódio do encontro com o menino às margens do rio de-Janeiro: "Foi um fato que se deu, um dia, se abriu. O primeiro".

O leitor é transportado assim, retrospectivamente, às origens da aventura romanesca, com o herói "embarcando" metafórica e literalmente em seu destino; na seqüência a leitura vai percorrendo, agora sob resguardo sistemático da ordem cronológica, os momentos fundamentais da história - captura e julgamento de Zé Bebelo, a vivência epifânica na Guararavacã do Guaicuí (revelação instantânea do amor), o ponto de virada que se configura com o assassinato de Joca Ramiro - até alcançar o trecho que já percorrera antecipadamente, graças ao narrar "dificultoso, muito entrançado" de Riobaldo. Metade da história já foi desdobrada ao leitor - ou toda ela, se este cumpriu a tarefa (irrealizável, porém, com uma única leitura) de captar os vários acenos e antecipações do narrador:

mas o que eu acho é que o senhor já sabe mesmo tudo - que tudo lhe fiei. Aqui eu podia pôr ponto. Para tirar o final, para conhecer o resto que falta, o que lhe basta, que menos mais, é por atenção no que contei, remexer vivo o que vim dizendo. Porque não narrei nada à-toa: só apontação principal, ao que crer posso. Não esperdiço palavras. Macaco meu veste roupa.

Da organização estética que preside à composição de Grande sertão: veredas pode-se afirmar de fato que não se dá "ponto sem nó" - não há, por assim dizer, "macaquices" ou "comportamento simiesco", e a metáfora em questão parece até mesmo ressoar no episódio do José dos Alves, confundido com um 
macaco durante a travessia do Liso e, por isso, abatido e assado pelos jagunços famintos. Em consonância com a impecável economia artística do livro, vemos as especulações do narrador sobre o bem e o mal ou sobre as formas de manifestação do diabo recuarem para um segundo plano com a abertura da história romanesca. Mas, se "causos" como o do Aleixo e do Pedro Pindó deixam de aflorar no relato, é em meio às vicissitudes da guerra, com Riobaldo ao lado de Hermógenes combatendo as forças de Zé Bebelo, que desponta a mais extraordinária história de reversibilidade do mal para o bem, fazendo ressoar em pleno sertão um motivo presente no Hamlet shakesperiano (a substância letal inoculada no ouvido do velho rei durante o sono) e trazendo também à lembrança a lenda em torno da Maria Aegyptiaca que, conforme narrado na coletânea Acta Sanctorum, é barrada à porta da igreja do Santo Sepulcro, em Jerusalém, por força misteriosa. Contudo, o caso de Maria Mutema é colocado na boca do jagunço Jõe Bexiguento, que reage com essa narrativa exemplar da tradição oral a uma indagação obsedante de Riobaldo, isto é, se jagunço poderia esperar o perdão e a graça de Deus.

Além disso, o caso de Maria Mutema foge para um ponto indeterminado do passado, fixado apenas no espaço físico, isto é, no sertão jequitinhão; pode muito bem ter ocorrido ainda antes do encontro entre Riobaldo e Diadorim às margens do rio e, portanto, antes do início da própria história épica. Se, ao abrir-se, essa suprime em larga medida as incursões especulativas do narrador, tal como desdobradas nos momentos iniciais do relato, poder-se-ia inferir daí que a questão do mal (e de seu entrelaçamento com o maligno) tenha perdido importância ou mesmo deixado de existir para Riobaldo?

Descortinando-se ao leitor o amplo painel épico da guerra jagunça, adentram o palco as personagens cujos nomes soaram pela primeira vez, mesclados com figuras históricas, pouco antes do episódio do encontro com o Jazevedão. São homens que, como sintetiza Riobaldo, "puxavam o mundo para si, para o concertar consertado", os quais irão cingir-se de grandeza mítica ("o mais supro, mais sério - foi Medeiro Vaz. [...] Joca Ramiro - grande homem príncipe”), mas também revestir-se de essência diabólica: o Hermógenes, de quem se diz já ter nascido "formado tigre, e assassim", e que irá assomar no romance, com crescente intensidade, como encarnação extrema do mal, num patamar muito diferente daquele em que se encontram figuras como o Aleixo ou o Pedro Pindó, Maria Mutema, Jazevedão (até este, vendo o sofrimento do menino Vâltei, "vinha com brutalidade de socorro") e mesmo o Ricardão, tão-somente um "bruto comercial" para Diadorim e, para o narrador, ambicionando apenas "ser rico em paz: para isso guerreava".

No extraordinário mundo de ambigüidades e reversibilidades configurado por Guimarães Rosa em seu romance, a figura do Hermógenes - em seu ser definitivo, inteiriço, infenso a dúvidas e hesitações - avulta como exceção à "verdade maior" riobaldiana de que "as pessoas não estão sempre iguais, ainda 
não foram terminadas - mas que elas vão sempre mudando". São traços, como sabemos, que se subordinam a uma malignidade irredutível, cujo pólo oposto parece constituir-se em torno de Joca Ramiro, que sobressai por semelhantes qualidades de firmeza. Mas suas aparições concretas se resumem a não mais do que três episódios e é sobretudo mediante a veneração de Diadorim que o seu nome desponta no romance. Também Riobaldo vai votando-lhe crescente admiração, a qual atinge o momento culminante no julgamento de Zé Bebelo. Armando-se nesse episódio o ponto de virada na história romanesca, Joca Ramiro vai ao encontro de seu destino como que mítico ("mesmo em quando ainda parava vivo, era como se já estivesse constando de falecido"), sepultando-se no chão de carnaúba de que falara a toada de Siruiz; ao mesmo tempo, a caracterização de Hermógenes ganha uma dimensão nova, pois se até então a imagem de "príncipe das tantas maldades" poderia ser atribuída a possível idiossincrasia do narrador em primeira pessoa, com o assassinato traiçoeiro a encarnação da "maldade pura", conjugada com o epíteto de Judas, salta para o plano da objetividade.

O que temos é que tanto na condição de aliado, nas fileiras sob o comando supremo de Joca Ramiro, assim como na condição de inimigo, após a traição, Hermógenes surge efetivamente como encarnação irreversível do mal, de um principium maleficum que não deve encontrar muitos paralelos na literatura ocidental. ${ }^{5}$ No plano da história ou fábula, o primeiro encontro do jovem Riobaldo com Hermógenes se dá na fazenda São Gregório, na madrugada em que ouve a canção de Siruiz. A mesma faculdade sensitiva que já o atraíra à esfera do menino Reinaldo-Diadorim provoca-lhe, à visão do Hermógenes, extrema repulsa, e neste ponto até se poderia pensar na reação instintiva que Goethe atribui a sua Gretchen em relação a Mefistófeles. A primeira impressão que Riobaldo tem de sua figura é poderosa e vem marcada, como já ressaltaram vários críticos, pelo elemento disforme, sinistro e ctônico ("quando ele caminhou uns passos, se arrastava - me pareceu - que nem queria levantar os pés do chão"). E, arrematando a percepção que se abrira com um traço afinado com a condição de pactário - ou seja, "homem sem anjo-da-guarda" -, tem-se o apelo ao bestiário, procedimento freqüente em caracterizações do demoníaco: Hermógenes é comparado ao "ser de uma irara, com seu cheiro fedorento".

Algum tempo depois, quando chega com Diadorim ao acampamento do “homem sem anjo-da-guarda", Riobaldo irá mobilizar uma expressão de sabor teológico para referir-se a esse espaço percebido logo como "inferno", e ao qual leva os três dias de forte simbologia bíblica para acostumar-se: “Ah, lá era um cafarnaum", como diz em alusão à cidade amaldiçoada por Jesus. Nesse "cafarnaum" Riobaldo realiza seu primeiro aprendizado da vida jagunça e aí tem oportunidade de conhecer de perto o gosto do Hermógenes - "fel dormido, flagelo com frieza" - em matar apenas por matar: "Nem contava valentias, vivia dizendo que não era mau. Mas, outra vez, quando um inimigo foi pego, ele 
mandou: - 'Guardem este.' Sei o que foi”. E, na seqüência, vem a descrição do terror do prisioneiro e da "alegria pior" reluzindo nos olhos do chefe do acampo, que passa horas afiando a faca. Para desviar-se da expressão fisionômica do seu superior, Riobaldo olhava para o seu pé - "enorme, descalço, cheio de coceiras, frieiras de remeiro do rio, pé-pubo" - e depois para as mãos, que percebe como as únicas capazes de executar "tanta ruindade".

A despeito dessa repulsa instintiva, contudo, a figura do Hermógenes, justamente por sua constituição compacta, pode também representar para Riobaldo uma esfera de segurança, como se observa no momento de uma escaramuça com tropas de Zé Bebelo. Mas se o herói busca aqui a proximidade protetora de um ser que pouco antes, "caraguejando" ao seu lado, dera-lhe a certeza de que "o inferno é mesmo possível [...] estava próximo de mim", o narrador não deixa de acrescentar que tal movimento contraditório é ditado expressamente pelo "meu cão de corpo".

Para esse personagem que veio ao mundo "formado tigre e assassim", motivações econômicas e políticas não parecem ser o motor primeiro de suas ações. É certo que durante o extraordinário episódio do julgamento de Zé Bebelo está em jogo, subterraneamente, uma disputa de poder e essa circunstância ajuda a entender a observação pontual do narrador (e talvez inconsistente à luz do todo) de que "no exatamente" era o Ricardão que mandava no Hermógenes. Pois a posição defendida por este decorre em primeiro lugar do desejo de executar barbaramente o prisioneiro - de preferência, "feito porco [...] Ou então botar atravessado no chão, a gente todos passava a cavalo por riba dele".

É, porém, com a traição ao "grande homem príncipe" que se abre a movimentada aventura romanesca, impensável na obra de um Marcel Proust, James Joyce ou Robert Musil. No epos de Guimarães Rosa, todavia, o leitor parece adentrar os domínios da célebre Frou Aventiure, como Wolfram von Eschenbach personifica no início do livro IX do seu Parzifal o espírito da fabulação cavalheiresca. Vestígios dessa tradição do Gral já foram levantados na fortuna crítica do Grande sertão. Mas a empresa guerreira de Riobaldo e Diadorim contra as hostes de Hermógenes poderia lembrar também, em certos lances, a mitologização da guerra que Novalis empreende em seu Heinrich von Ofterdingen - romance que, conforme demonstra Suzi Frankl Sperber, foi lido e anotado por Rosa. ${ }^{6}$

Como se sabe, Novalis ambienta o seu fragmento romanesco no mesmo período da Idade Média (início do século XIII) em que Wolfram redige a história de seu Parzifal. Se, também por força dessas sugestões literárias, o leitor de Rosa pode eventualmente sentir-se transportado a uma fase arcaica das formas épicas, também a concepção do mal porventura subjacente ao personagem do Hermógenes pode levar a um recuo significativo na história do pensamento filosófico e teológico, a um estádio ainda anterior às reflexões kantianas sobre o mal - e, em particular, sobre o "mal radical", tal como desenvolvidas na obra tardia A religião nos limites da simples razão. 
Lembremos que o próprio Goethe se equivocou na interpretação desse conceito de "mal radical", entendendo-o como uma restrição à idéia da liberdade humana. ${ }^{7}$ Valendo-nos, mesmo assim, da imagem mobilizada pelo autor do Fausto em sua observação sobre o velho filósofo de Königsberg, não poderíamos dizer talvez que Guimarães Rosa, se não conspurcou o seu "manto poético", carregou em excesso nas tonalidades míticas com a construção de um personagem irredutível e incondicionalmente maligno - também associado a um demônio cujas fulgurações se dão sempre no âmbito do ominoso? Pois Hermógenes assoma no romance enquanto encarnação consumada não do mal "radical" (que no limite se constitui ainda enquanto um malum defectus), mas antes de um malum privationis, daquele mal a que Kant chama de "diabólico". ${ }^{8}$

O leitor do romance brasileiro encontra-se neste ponto muito distante do proteiforme Mefistófeles goethiano: certamente diabólico por vezes, mas com freqüência irreverente, paradoxal, irônico e auto-irônico, não raro também pusilânime. De resto, o mal incondicional, absoluto, não era de modo algum coisa do poeta alemão que já em 1771 - portanto aos 22 anos de idade - proferia as seguintes palavras por ocasião de um discurso em homenagem a Shakespeare: “aquilo que nomeamos como mal é apenas o outro lado do bem, tão necessário para a sua existência e parte integrante do todo, assim como a Zona torrida deve arder e a Lapônia congelar, para que haja uma região temperada". A afirmação é altamente questionável, mas não vem ao caso examiná-la agora de perto. Lembremos apenas que mais tarde Goethe recebeu com bonomia e complacência a declaração de Madame de Staël de que teria desejado um Mefistófeles mais terrível. E, dessa mesma perspectiva, lamentou que John Milton tivesse colocado em cena, em seu Paradise lost, um Satã tão incondicionalmente maligno.

O leitor que se inclinar a essa visão goethiana do mal e do maligno estará porventura inteiramente receptivo ao diabo pusilânime e queixoso - ainda por cima acometido de reumatismo - que, no derradeiro romance de Dostoiévski ( $11^{\circ}$ capítulo do $9^{\circ}$ livro), surge a Ivan Karamázov, arquiteto frio e manipulador, mas de modo algum movido pelo mal "diabólico" (em sentido kantiano), do assassínio do próprio pai. Todavia, esse mesmo leitor talvez possa estranhar no romance rosiano a debilidade de motivações ou condicionamentos exteriores para a maldade que anima os atos do Hermógenes. Parece avultar aqui uma malignidade como que supra-histórica (ou "metafísica", dimensão que Rosa, como sabido, considerou tão importante para o romance), a que talvez estejam relacionados outros traços perceptíveis no romance brasileiro, em particular a ausência de passagens em que se desvendem criticamente contradições da realidade brasileira, em que se delineie uma exposição mais complexa da injustiça social que, no entanto, o leitor percebe vigente por trás dos episódios narrados. Pois não se poderia dizer que, ao contrário do que acontece no mundo sertanejo de Graciliano Ramos, em Grande sertão: veredas a miséria mostra via de regra uma face naturalizada, mais amena, "interessante" do ponto de vista artístico? 
Digno de nota é também, contemplando as coisas dessa perspectiva, que uma figura histórica como o coronel Rotílio Manduca, representante de um dos aspectos mais sinistros da realidade brasileira, desponte três vezes no relato romanesco sem dar azo a qualquer comentário que vá além da simples referência às "duzentas mortes" encomendadas. ${ }^{9}$

De qualquer maneira não será definitivamente na dimensão política ou ideológica que reside a grandiosidade desse nosso romance. Mas, para lançar uma nova luz sobre a argumentação em andamento e matizar pelo contraste a noção do mal subjacente ao personagem do Hermógenes - "cavaleiro felão, traidor do preito e da devoção tributada ao suserano", como formulado por Antonio Candido (1978) -, o passo seguinte pretende recorrer mais uma vez à perspectiva comparativa e incursionar por uma narrativa que o próprio Guimarães Rosa reputou muito importante para a concepção de seu mundo épico. Trata-se da principal obra do barroco alemão, Der abentheurliche Simplicissimus Teutsch, publicada em 1668 por Hans J. C. von Grimmelshausen. ${ }^{10}$ Temos aqui o mais amplo e vigoroso painel da Guerra dos Trinta Anos (1618-1648), narrado com precisão realista combinada com uma perspectiva rasteira da história e da sociedade, num tom plebeu guiado pela proposta satírica de "dizer a verdade rindo". Apesar da distância temporal e espacial que separa os dois romances, é plenamente possível vislumbrar afinidades entre o mundo da jagunçagem rememorado pelo velho Riobaldo no refúgio de sua fazenda e, três séculos antes, o mundo da soldadesca vivenciado por Simplicissimus durante a guerra e reconstituído posteriormente, em sua existência pia numa ilha deserta, com tinta extraída do sumo de pau-brasil e um pergaminho de folhas secas de palmeira.

\section{O mal no Simplicissimus: um recuo à Guerra dos Trinta Anos}

Para o passo comparativo a ser dado aqui, vamos tomar entre os incontáveis personagens que cruzam o caminho do ingênuo Simplicius Simplicissimus (ao qual também caberia a designação de "pobre menino do destino"), aquele que assoma como encarnação extrema do mal num mundo configurado já per se como intrinsecamente mau. Trata-se de Olivier, com quem o herói trava contato no $21^{\text {O }}$ capítulo do segundo livro. $\mathrm{O}$ palco da ação é agora um acampamento imperial e saxão nas imediações da cidade luterana de Magdeburg (inteiramente destruída em 1631 por forças católicas), para onde o herói é conduzido por soldados que o capturam numa floresta, após já ter passado por inúmeras aventuras em meio a tropas suecas, croatas e alemãs. Nesse acampamento, Simplicissimus fica conhecendo não apenas o maligno escrivão Olivier, mas também o jovem Herzbruder, filho de um honrado mestre de cerimônias dotado de capacidades adivinhatórias, a quem o herói se encontra subordinado enquanto espécie de bufão do regimento. A partir desse momento, a trajetória do protagonista será balizada em suas principais estações pelo contato com Herzbruder e Olivier, entre os quais irá oscilar como entre os pólos do bem, indiciado já pelo expressivo nome que significa "irmão" (Bruder) do "coração" (Herz), e de um mal 
elementar. Se o intrigante escrivão tem, perante o herói, comportamento amistoso nos episódios do segundo livro, isso se deve à profecia do velho mestre de cerimônias de que Simplicissimus vingaria a morte de Olivier, o que de certo modo irá acontecer no final do quarto livro. Quanto ao jovem Herzbruder, porém, Olivier consegue emaranhá-lo num ardil que o faz cair em desgraça e por pouco não o leva à forca.

Por meio dos desastres da Guerra dos Trinta Anos, os caminhos de Simplicissimus e Herzbruder irão ainda cruzar-se em episódios cruciais do terceiro e do quarto livros, colocando-os sempre numa relação de solidariedade fraternal. Já Olivier atua sob disfarce em capítulos do terceiro livro, mas volta a irromper inesperada e brutalmente na vida do herói no 14 o capítulo do quarto livro, ao assaltá-lo enquanto atravessava a Floresta Negra a caminho de Estrasburgo, pouco depois de ter escapado de tropas francesas: trata-se, como formula o título do capítulo, de "um perigoso duelo pela vida e pela pele, mas do qual ambos se safam da morte". Esgotados pela longa e encarniçada luta, os dois acordam em fazer as pazes, o que leva de imediato à cena do reconhecimento.

Os dez capítulos subseqüentes são dominados então pela figura de Olivier, que passa a relatar os latrocínios que vem cometendo em sua existência de salteador, à qual procura conferir aparência e dignidade de um Raubritter. ${ }^{11}$ Reproduzido minuciosamente ao longo de várias páginas, o relato desdobra ao leitor requintes de crueldade, mesmo para os padrões da Guerra dos Trinta Anos. Complementando o relato, ainda vemos Olivier agir diretamente, como no $22^{\circ}$ capítulo desse quarto livro: após deter uma carruagem e abater a tiros e a golpes de machado os dois cocheiros, parte para o massacre de três crianças e duas mulheres, no que é, porém, impedido por Simplicissimus. Contrariado em seu propósito, Olivier apresenta argumentos políticos e econômicos para justificar seu intento, os quais se abrem com as palavras "ovos à frigideira", ou seja, as crianças pertencem à classe dominante e é preciso eliminá-las antes que se transformem em parasitas e exploradores do povo. ${ }^{12}$ Argumentos semelhantes o herói ouve no alto de uma torre de igreja, que funciona como posto de observação para os assaltos; agora é plenamente conseqüente que seja sobretudo a hipocrisia religiosa (a vaidade e ostentação exibidas durante a missa) a cair sob a crítica de Olivier - crítica que se revela, aliás, tão mais aguda se considerarmos que o ensejo primeiro para a deflagração da guerra originou-se de disputas religiosas.

O capítulo que traz essa conversa no alto da torre intitula-se "Os pensamentos de Simplicius ao sair para assaltos são mais edificantes do que os de Olivier na igreja", também aqui se revelando o gosto do escritor barroco por longos títulos - formulados na linguagem que atravessa todo o romance, vazada em verve satírica, recheada de provérbios, adágios, saborosas expressões populares. O mesmo se observa, portanto, dois capítulos antes, quando Simplicissimus reprova as crueldades cometidas pelo companheiro, que seriam contrárias tanto 
às leis da Natureza como às de Deus, e que cedo ou tarde o levariam à forca, pois "tantas vezes o jarro vai à fonte que um dia quebra"; além disso, a maneira como Olivier levava a vida seria "a mais vergonhosa do mundo". A resposta, da qual se apresenta abaixo apenas um trecho, é longa e enfática - mas extraordinário também o empenho em inserir a práxis individual na respectiva realidade histórica:

Como, a mais vergonhosa? Meu bravo Simplício, eu lhe asseguro que a vida de assaltante é o mais nobre exercício que se pode ter no mundo nestes tempos. Diga-me, quantos reinos e principados não foram conquistados e instituídos com violência? [...] O que poderia ser considerado mais nobre do que exatamente esse ofício de que estou me servindo agora? Eu percebo que você gostaria de replicarme que não poucos foram desmembrados na roda, enforcados ou decapitados por causa de homicídio, roubo ou furto; sei disso muito bem, pois é o que ordenam as leis, mas você não verá ninguém balançar na forca a não ser ladrões miúdos, o que também é legítimo pois se lançaram a essa atividade primorosa, que está reservada e não cabe a ninguém mais do que a espíritos arrojados. Você viu alguma vez uma pessoa de condição social elevada ser punida pela justiça pelo fato de ter explorado e sugado em demasia suas terras e subordinados? E, para não ficar só nisso, se não se pune nenhum usurário que pratica secretamente essa magnífica arte, e na verdade sob o manto da caridade cristã, por que eu então deveria ser punido, eu que assumo abertamente minhas práticas, à boa e velha maneira teutônica, sem nenhuma hipocrisia ou dissimulação? Meu caro Simplício, você ainda não leu Maquiavel; eu tenho um caráter bastante íntegro e levo esse modo de vida livre e abertamente, sem vergonha alguma; arrisco a minha vida empunhando a espada, como os antigos heróis, e sei assim que são permitidos aqueles atos quando realizados por quem se coloca em situação de risco; e por colocar, portanto, minha vida em perigo, daí decorre de modo irrefutável que me é permitido e legítimo praticar essa arte.

Após reiteradas objeções do seu interlocutor, Olivier volta a justificar-se sumariamente com o autor do Príncipe: “É como eu já disse, você é ainda o Simplício que não estudou Maquiavel; mas se eu pudesse por esses meios erigir uma monarquia, então eu queria ver quem faria sermões contra mim".

A reprodução do longo trecho, algo excessivo no âmbito de um ensaio sobre Grande sertão, tem apenas a finalidade de expor a plasticidade histórica que Grimmelshausen confere à figura emblemática do mal no Simplicissimus e, desse modo, estabelecer um plano de contraste para compreensão mais ampla e matizada do personagem correspondente no romance brasileiro. Longe da intenção moralizante do autor barroco querer justificar, ainda que apenas parcialmente, as ações de Olivier com uma dinâmica histórica reconhecida como intrinsecamente perversa, sobretudo durante essa época marcada pelo "monstro cruel e horrível" da guerra. Mas igualmente distante de Grimmelshausen - e aqui se revela diferença fundamental em relação à construção da figura de Hermógenes - colocar em cena um mal com ressonâncias míticas, ou seja, que não esteja fundamente enraizado nessa mesma dinâmica histórica e que, portanto, não mantenha vínculos estreitos com a barbárie que, na ótica final do narrador, rege a vida dos homens. 
É claro que o recurso a Maquiavel configura-se, na boca do maligno Olivier, como inteiramente ideológico, uma distorção do tratado renascentista com a finalidade única de conferir legitimidade aos crimes que perpetra em seu piccolo mondo. Dificilmente se poderia atribuir a Grimmelshausen um tal aproveitamento do Príncipe, mas à perspectiva crítica que subjaz ao romance não é estranho o paralelo entre a "arte" professada por Olivier e as práticas no mundo da alta política e dos grandes interesses econômicos. À luz de passagens como a anteriormente reproduzida, podemos admirar o potencial crítico do romance barroco e, ao mesmo tempo, compreender o forte interesse que despertou em autores como Brecht, Thomas Mann ou Günter Grass. Se Guimarães Rosa ressalta a importância do Simplicissimus para a concepção de seu próprio romance, essa dimensão de crítica social (que ainda hoje preserva sua atualidade), de representação rasteira e plebéia da história, não parece ter deixado marcas especialmente profundas no relato de Riobaldo.

Sob outros aspectos, no entanto, a aproximação entre as duas obras pode revelar-se fecunda e elucidativa, não obstante os três séculos que as separam. Saltam aos olhos, em primeiro lugar, as afinidades na caracterização épica dos deslocamentos e das práticas da jagunçagem e da soldadesca durante a Guerra dos Trinta Anos - os marodeurs aos quais Simplicissimus por vezes se associa e nos quais o narrador enxergará posteriormente a negação de todos os princípios cristãos (do mesmo modo como, para o velho Riobaldo, o jagunço convicto, que "se entrete" nessa condição, aparece como "entrante do demônio"). $\mathrm{Na}$ reconstituição e elaboração das aventuras vividas em meio às reviravoltas e vicissitudes da guerra, ambas as narrativas em primeira pessoa impregnam-se de expressivo substrato religioso, de tal forma que a confiança ou, antes, a aposta na providentia Dei acaba por constituir-se em espécie de viga mestra da concepção de mundo e de vida dos narradores.

Como a maioria dos romances de aventura que realmente contam, tanto o Simplicissimus como o Grande sertão suscitam reflexões quanto à sua inserção na tradição do Bildungsroman - afinal, conforme se exprimiu Thomas Mann, que outra coisa seria esse tipo narrativo "senão uma sublimação e espiritualização do romance de aventuras"? Mas os acenos religiosos das obras, também o desfecho adverso, e até mesmo trágico, a partir do qual começa a se formar a perspectiva da narração, não seriam argumento contrário a uma tal inserção? Esse argumento parece valer especialmente para Simplicissimus, cuja travessia pela Guerra dos Trinta Anos encontra o seu termo no motivo barroco do desengaño, na renúncia radical ao mundo, que se concretiza por fim em seu insulamento. Como aceitar assim a avaliação do romance enquanto obra precursora do Bildungsroman, postulada por não poucos críticos renomados, entre os quais Otto Maria Carpeaux? Pois com sua fuga a toda forma de convívio humano, o Simplicissimus já contraria frontalmente o modelo paradigmático que Goethe proporia no final do século XVIII com Os anos de aprendizagem de Wilhelm Meister. Para o ere- 
mita resignado em que se converte o herói de Grimmelshausen, a alternativa de retornar à Europa e integrar-se à sociedade do pós-guerra significa ceder à ilusão de que a história humana passou finalmente a ser regida por princípios cristãos e não mais por aqueles expostos pelo maligno Olivier em seu discurso de legitimação.

Quanto a Riobaldo, suas andanças e vivências em meio à grande guerra jagunça encenada por Guimarães Rosa - em especial a relação com Diadorim e o confronto com a forma diabólica do mal encarnada em Hermógenes - perfazem uma trajetória que envolve igualmente princípios e fundamentos da tradição do romance de formação e desenvolvimento. Ao contrário de Simplicissimus, contudo, Riobaldo passa por uma experiência que se converte na questão crucial de sua existência e que, de resto, excluiria radicalmente a alternativa de todo processo paulatino de aperfeiçoamento individual, de amadurecimento e aprendizagem. Essa experiência, a que Grimmelshausen apenas alude em seu romance, está relacionada ao antigo motivo literário do pacto demoníaco. ${ }^{13}$ Impõe-se assim que, encerrada essa incursão pela Guerra dos Trinta Anos guiada pela imagem do mal que toma forma na figura de Olivier, a atenção se volte, ainda em chave comparativa, à configuração de tal motivo no Grande sertão e, em seguida, à oscilação do herói entre a tradição fáustica e o caminho da formação e do desenvolvimento.

\section{Notas}

l Citado segundo a tradução de Jenny Klabin Segall (Goeth, 2004, v.1342-4).

2 A esse respeito ver o livro de Susan Neiman (2003).

3 A expressão é tomada ao célebre ensaio de Walter Benjamin "O narrador".

4 As considerações musilianas sobre o esgarçamento do "fio narrativo" encontram-se no $122^{\circ}$ capítulo do seu romance, intitulado Heimweg [A caminho de casa].

5 Pode-se pensar talvez na perfídia gratuita com que Iago conduz Otelo ao assassínio de Desdêmona, instilando-lhe o ciúme. Do romance Berlim Alexaderplatz, de Döblin, vem a lembrança do enigmático Reinhold - rosto comprido e vincado, olhos sempre tristes, muito gago - a quem se devem os dois acontecimentos cruciais na vida do herói: a perda do braço e o estupro e estrangulamento de Mieze.

6 Ver a esse respeito o capítulo "Caos e cosmos" de Sperber (1976, p.120-2). A eventual influência de Novalis pode ser vislumbrada no oitavo capítulo do Ofterdingen, que traz a conversa entre Klingsohr e o seu jovem discípulo sobre os mistérios da poesia e da guerra.

$7 \mathrm{Na}$ célebre carta endereçada a Herder no dia 7 de junho de 1793, Goethe escreve que Kant teria, com a sua concepção do "mal radical", "lambuzado" [beschlabbert] o seu manto filosófico.

8 Pois o mal "diabólico" (teuflisch) para Kant - tal como referido no mencionado tratado ( 1 a parte, $3^{3}$ seção) - não remonta a um defeito da vontade, como é mais próprio do ser humano, mas seria intrínseco a uma mentalidade que elegeu como máxima a prática do mal pelo mal. 
9 Sobre a figura histórica do coronel Rotílio Manduca, ver Coelho (2003).

10 O romance compõe-se de cinco livros e uma "continuação" (Continuatio des abentheurlichen Simplicissimi), publicada no ano seguinte (1669) por um suposto editor chamado German Schleifheim von Sulsfort, um dos inúmeros anagramas que ocultaram a identidade do autor até 1837. Na entrevista que concedeu a Günter Lorenz, Rosa (1991) ressalta o seu apreço pelo Simplicissimus.

11 Literalmente, Raubritter significa algo como cavaleiro "rapinante", "salteador". Trata-se de um fenômeno característico da Baixa Idade Média: muitas vezes nobres empobrecidos que tiravam o seu sustento de assaltos cometidos nas estradas, ou que então saíam para fazer justiça com as próprias mãos.

12 Em vez de chacinar também as mulheres e as crianças, Olivier concorda em amarrá-las no porão de uma casa abandonada. Em seguida, Simplicissimus depara, numa floresta, com o cadáver enregelado de um judeu, que Olivier declara haver assaltado e depois amarrado a uma árvore, para morrer de fome e frio; considera então, pesaroso, que as mulheres e crianças teriam provavelmente o mesmo destino.

13 Durante sua estada na estância mineral de Sauerbrunnen, onde Herzbruder encontra a morte em vez da cura almejada, Simplicissimus tem contato com um suposto pactuário, em episódios ( $6^{\circ}$ e $7^{\circ}$ capítulos do livro $\mathrm{V}$ ) que aludem ao livro popular Historia von D. Johann Fausten.

Referências bibliográficas

CANDIDO, A. O homem dos avessos. In: Tese e antítese. São Paulo: Cia. Editora Nacional, 1978.

COELHO, M. A. As diversas vidas de Zé Bebelo. Estudos Avançados, n.49, set.-dez. 2003. Disponível em: <http://www.scielo.br/scielo.php?script-sci_arttext\&pid-S0103-40142003000300021\&lng-pt\&nrm-iso\&tlng-pt>.

DOSTOIÉVSKI, F. Os irmãos Karamázov. Trad. Paulo Bezerra. São Paulo: Editora 34, 2008. livro XI, cap.10.

GOETHE, J. W. von. Fausto. Uma tragédia - Primeira Parte. Trad. Jenny Klabin Segall. São Paulo: Editora 34, 2004.

NEIMAN, S. O mal no pensamento moderno. Rio de Janeiro: Difel, 2003.

ROSA, J. G. Diálogo com Guimarães Rosa. In: Coleção Fortuna Crítica. Org. por Eduardo F. Coutinho. Rio de Janeiro: Civilização Brasileira, 1991.

SPERBER, S. Caos e cosmos - Leituras de Guimarães Rosa. São Paulo: Livraria Duas Cidades, 1976.

RESUMO - Este texto constitui o segundo capítulo de um estudo sobre a trajetória de Riobaldo em sua oscilação entre o pacto fáustico e a tradição do chamado "romance de formação e desenvolvimento" (Bildungs-und Entwicklungsroman). Partindo de um trecho do romance $O$ homem sem qualidades em que Musil discute os obstáculos que se colocam à arte da narrativa no século XX (antecipando reflexões teóricas de Adorno, 
Auerbach, Rosenfeld etc.), o estudo enfoca, no primeiro capítulo, traços do Grande sertão que o vinculariam a um épico mais primitivo. Também se estabelecem aqui algumas relações com o Doutor Fausto de Thomas Mann, romance que tem igualmente no pacto demoníaco o seu motivo nuclear. Quanto ao presente texto, está voltado às formas e imagens que o relato de Riobaldo dispensa aos conceitos de "mal" e de "maligno" (assim como ao seu entrelaçamento). Em seguida, enfoca a personagem de Hermógenes, que encarna uma espécie de principium maleficum que dificilmente encontra paralelo na literatura ocidental. Para expor essa especificidade da personagem rosiana, o estudo procede por fim a uma comparação com a representação do Mal (e sua correspondente personagem) no romance barroco Simplicissimus, de Grimmelshausen.

PALAVRAS-CHAVE: Grande sertão: veredas, Doutor Fausto, Simplicissimus, Imagens do mal e do maligno, Pacto fáustico, Romance de formação.

ABSTRACT - This text represents the second chapter of a study on Robaldo's trajectory during his oscilation between the faustian bargain and the tradition of the so-called "Bildungsroman" (Bildungs - und Entwicklungsroman). Taking an excerpt of the novel The Man Without Qualities, in which Musil discusses the obstacles imposed on 20th century narrative art, as a starting point (and putting forth theorethical reflections by Adorno, Auerbach, Rosenfeld etc.), the essay focuses, in the first chapter, on the features of Guimarães Rosa's novel The Devil to Pay in the Backlands that would connect it to a more primitive epic. Here, some relationships with Thomas Mann's Doctor Faustus, which also has the diabolic pact as a central motif, are established. As to the present text, it is directed towards the shapes and images that Riobaldo's report gives to the concepts of "evil" and "devil" (as well as their interminglement). Then, it focuses on the character Hermógenes, who embodies a kind of principium maleficum, which can hardly find a parallel in Western literature. In order to expose this specifity of the Rosian character, the study goes on to a comparision with the representation of Evil (and its corresponding character) in Grimmelshausen's barroque novel, Simplicissimus.

Kerwords: The Devil to Pay in the Backlands, Doctor Faustus, Simplicissimus, Images of evil and devil, Faustian bargain, Bildungsroman.

Marcus V. Mazzari é professor de Teoria Literária e Literatura Comparada na USP. Traduziu textos de Heine, Chamisso, Marx, Walter Benjamin, Thomas Mann, Günter Grass, Brecht, entre outros. Entre suas publicações constam Romance de formação em perspectiva histórica (Ateliê Editorial, 1999) e, mais recentemente, notas, comentários e apresentações ao Fausto I (Editora 34, 2004) e Fausto II de Goethe (Editora 34, 2007), em tradução de Jenny K. Segall. @ - mazzari@usp.br

Recebido em l⿳⺈.10.2008 e aceito em 8.10.2008. 